\title{
Performance of Multivoltine Silkworm Races on M-5 Variety of Mulberry (Bombyx Mori L)
}

\author{
${ }^{1}$ S. A. Shendage, ${ }^{2}$ P. A. Bothikar, ${ }^{3}$ C. B. Latpate \\ Department of Entomology, C.S.M.S.S. College of Agriculture, Kanchanwadi, Aurangabad- 413 001, \\ Maharashtra, India. \\ Department of Entomology, C.S.M.S.S. College of Agriculture, Kanchanwadi, Aurangabad- 413 001, \\ Maharashtra, India. \\ Ph. D. Assistant Professor Department of Entomology, V.N.M.K.V College of Agriculture, Parbhani \\ Maharashtra, India
}

\begin{abstract}
The studies on nine different multivoltine races viz., Pure Mysore, Hosa Mysore, Mysore Princes, Kolar Gold, C. Nichi, G Race, $P_{2} D_{1}, C B_{5}$ and Nistari on M-5 variety of mulberry larval duration, weight of ten matured larvae, diseases mortality (\%), single cocoon weight, denier and fecundity were undertaken during 2012-13. The studies shows that Kolar Gold race was recorded superior for weight of the ten mature larvae $(22.16 \mathrm{~g})$, Pure Mysore was recorded significantly superior for incidence of disease (1.50\%) and fecundity (508.61 eggs). The race $P_{2} D_{1}$ found superior for single cocoon weight $(0.980 \mathrm{~g})$ and cocoon yield $(9.800 \mathrm{~kg})$. The race C.Nichi was recorded superior for denier (1.68) and larval duration (22.96). Hosa Mysore race (16.10\%) was found significantly superior over rest of the races for shell ratio.

Key Words: Fecundity, Larval duration, Deneir, Cocoon yield, Shell ratio, Bombyx mori L.
\end{abstract}

\section{Introduction}

A class fiber of insect origin, mulberry silk is the end product of sericulture activity and occupies a prestigious position in the world. In view of being oldest world trade commodity it has, through all days received a worldwide importance. Despite several attempts of man to create an artificial substitute for this natural thread, none could match its grace, luster, suppleness, lighter weight, durability, tenacity and many other excellent qualities. Sericulture is labour intensive, export oriented, employment creating and income generating agro-based cottage industry providing quick return in shorter duration and does not involve utilization of sophisticated machinery.

Sericulture having tremendous potential of employment generation and capacity of earning foreign exchange. It provides employment to about 60 lakh people in rural areas in the country. Out of which woman constitute about 60 per cent contribution. By producing self employment in rural areas, not only the rural migration is arrested but also the cottage and small industries get established in rural India. One hectare of land under mulberry in terms of productivity yield Rs 80,000 worth of silk, which is quite attractive as compared to the other commercial crops. In addition, it creates employment to 12-13 persons annually in mulberry cultivation, silkworm recycling, twisting and post harvest cocoon technology like weaving and fabrication of implements (Meenakshisundaram, 1983).

\section{Material And Methods}

The experiment was conducted in rearing house at Department of Agricultural Entomology, College of Agriculture, Latur. Before starting the experiment the rearing room was disinfected daily two times with the help of $2 \%$ Formalin solution and $0.3 \%$ Bleaching powder. All the rearing equipments were also disinfected. The rearing room temperature was maintained at $24^{\circ} \mathrm{C}$ to $28^{\circ} \mathrm{C}$. Disease free layings (Dfl's) of nine parental lines viz., Pure Mysore, Hosa Mysore, Mysore Princes, Kolar Gold, C. Nichi, G Race, $\mathrm{P}_{2} \mathrm{D}_{1}, \mathrm{CB}_{5}$ and Nistari of multivoltine silkworm germplasms were procured from the Central Sericultural Germplasm Resource Centre, Hosur, Tamil Nadu and which was used as an experimental material. The Dfl's of parental races were properly black boxed at pin head stage and incubated at $25^{\circ} \mathrm{C}$ and $70 \%$ relative humidity for 48 hrs.before hatching. During this period care was taken to protect the eggs from predators. Before hatching the eggs were exposed to sun light in morning hours for few minutes to promote the uniform hatching of larvae from eggs. Krishnaswami (1978) described the improved technology of silkworm rearing and it was adopted in this investigation. The newly hatched larvae were fed with recommended size chopped pieces of fresh mulberry leaves of M-5 variety, 100 larvae of each race treated as one replication were kept in 36.6" x 36.6" wooden tray. The rearing trays were arranged at randomized manner in each replication to minimize the experimental error. The leaves were chopped into small pieces of $0.5 \mathrm{~cm}$ and sprinkled over the newly hatched worms for their feeding. The feeding was given four times in a day, at $8.00 \mathrm{hrs}, 12.00 \mathrm{hrs}, 16.00 \mathrm{hrs}$ and $21.00 \mathrm{hrs}$. The rearing trays were cleaned 
daily as per recommendation. The maximum larval weight was recorded by taking the weight of randomly selected 10 matured larvae just before the onset of spinning. The fecundity of each race was computed by taking average number of eggs laid by three female moth of each race. Percentage incidence of diseases were worked out as below,

$$
\begin{aligned}
& \text { Disease } \%= \\
& \text { No. of diseased larvae } \\
& \text { Total No. of larvae }
\end{aligned}
$$

Denier is the term used to denote the thickness of silk filament and expressed in terms of ratio of weight of filament, to the filament length multiplied by 9000 . Nanvathy (1965).

$$
\text { Denier }=\frac{\text { Filament weight }(\mathrm{g})}{-------------------} \text { x } 9000
$$

\section{Results And Discussion}

Significantly positive larval duration of 22.96 days was recorded by C.Nichi. The races $\mathrm{CB}_{5}(23.26$ days), Hosa Mysore (23.27 days) and Mysore Princess (23.37 days) were found at par with each other, whereas the highest larval duration was observed in Pure Mysore (29.53 days). Tayade (1983) reported that the larval duration was longer in race Pure Mysore (32 days).

The performance of the race Kolar Gold $(22.16 \mathrm{~g})$ for weight of ten mature larvae was observed significantly superior over the rest of the races, except $\mathrm{P}_{2} \mathrm{D}_{1}(21.30 \mathrm{~g})$, Hosa Mysore (21.02 g), $\mathrm{CB}_{5}(20.61 \mathrm{~g})$ and $\mathrm{G}$ Race $(20.42 \mathrm{~g})$ which were at par with each other whereas, the lowest larval weight was recorded in Pure Mysore (15.45g).

The highest single cocoon weight was recorded in the race $\mathrm{P}_{2} \mathrm{D}_{1}(0.980 \mathrm{~g})$ over rest of the races. The race Kolar Gold $(0.970 \mathrm{~g})$ and Hosa Mysore $(0.935 \mathrm{~g})$ were found at par with each other. Whereas, the lowest single cocoon weight was recorded by Pure Mysore (0.646 g). Swamy (1999) reported that the highest single cocoon weight was recorded in $\mathrm{P}_{2} \mathrm{D}_{1}(1.38 \mathrm{~g})$. Chattopadhyay et al., (1992) reported that the highest single cocoon weight was recorded in OS-616 (1.27 g). The single cocoon weight recorded by $\mathrm{P}_{2} \mathrm{D}_{1}$ at Central Sericultural Germplasm Resources Center, Hosur is $1.306 \mathrm{~g}$.

Significantly lowest disease incidence was recorded by Pure Mysore (1.50\%). Followed by the races Kolar Gold (1.90\%), the maximum disease incidence was recorded by Hosa Mysore (7.85\%).

The denier of race C.Nichi (1.68) was observed significantly superior over the all other races tested. Whereas, the denier of $G$ Race (1.72) and $\mathrm{P}_{2} \mathrm{D}_{1}$ (1.76) were found at par with each other. The lowest performance was recorded by Hosa Mysore (2.00). Latpate (1997) reported that the highest denier was recorded in $\mathrm{MY}_{1}$ (2.597) whereas the lowest denier was recorded in C. Nichi (1.423). Narayanaswamy (2000) showed that highest denier was recorded in Pure Mysore (2.77) followed by $\mathrm{P}_{2} \mathrm{D}_{1}(2.47)$.

The maximum shell ratio was observed in the Hosa Mysore $(16.10 \%)$ and was found significantly superior over rest of the races tested except, $\mathrm{P}_{2} \mathrm{D}_{1}(15.30 \%)$, $\mathrm{G}$ race $(15.02 \%), \mathrm{CB}_{5}(14.77 \%)$, C. Nichi $(14.75 \%)$ and Mysore Princess (14.67\%) which were at par with superior race Hosa Mysore. The minimum shell ratio was recorded by Kolar Gold (13.94\%).

The highest cocoon yield was recorded by the race $\mathrm{P}_{2} \mathrm{D}_{1}(9.800 \mathrm{~kg})$, followed by Kolar Gold $(9.700$ $\mathrm{kg}$ ), Hosa Mysore $(9.350 \mathrm{~kg}$ ) and C. Nichi $(9.307 \mathrm{~kg})$. The lowest cocoon yield was recorded by Pure Mysore $(6.467 \mathrm{~kg})$.

The fecundity was varied in the range 508.61 eggs to 431.63 eggs. The maximum fecundity was observed in Pure Mysore (508.61 eggs) and was significantly superior over rest of races except, Kolar gold (481.65 eggs) and $\mathrm{CB}_{5}$ (462.96 eggs), which were at par with each other. The minimum fecundity was recorded by the C.Nichi (431.63 eggs).

\section{Referances}

[1]. Ananatnarayana (2000). Study of performance of some mulberry silkworm for different economic traits. Indian J. of Sericulture, Dec 2001, pp: 48-50

[2]. Biabani, M.R.; Gholami, M.R.; (2003). Resistance evaluation of pure lines of Silkworm (B. mori L.) against the pathogen of white muscardine disease Beavera bassiana. Iranian J. of Agri. Sciences, 34(3): 701-710.

[3]. Chattopadhyay, S., Ghosh, B., Rao, P.R.T., Sudip Sen, Gupta, S.K., Roy, G.C., Sen, S.K. and Das, S.K. (1992). Analysis of quantitative traits in some evolved multivoltine silkworm breeds of B. mori L. under two environments. Environ. Ecol., 10 (4): 845 848.

[4]. Krishnaswami, S. (1983). Evolution of new bivoltine recs for traditionally multivoltine areas of South India. Indian Silk, 22 (1): 3 11.

[5]. Latpate, C.B. (1997). Breeding of silkworm, B. mori L. for better economic traits in Marathwada region. Ph.D. Thesis, Marathwada Agricultural University, Parbhani (Unpublished).

[6]. Meenakshisundaram, S.S. (1983). Intensifying field oriented research : A must. Indian Silk, 21(2):3-8.

[7]. Nanvathy, M.N. (1965). Silk from grub to glamer, paramount, Ph. D. Thesis, University of Mysore, 277P. 
[8]. Narayanswamy, T.K. (2000). Performance of bivoltine x multivoltine cross breeds of silkworm for cocoon and silk traits. Indian J. Seric., 39 (2): 165-168.

[9]. Saydavi, A. (2003). Resistance evaluation of pure lines of silkworm B. mori L. against the pathogen of white muscardine disease, Beauveria bassiana. Iranian J. of Agric. Sciences, 34 (3): 701-710.

[10]. Swamy (1999). Performance of traditional multivoltine races of silkworm (B. mori L.) in non-traditional belt of North Karnataka. Indian Acad. Seric., pp: 12-15.

[11]. Tayade, D.S. (1983). The feasibility and profitability of mulberry silkworm (B. mori L.) under Marathwada conditions. Res. Bull, Marathwada Agricultural University, Parbhani. 7: 53-58.

[12]. Watanabe, K. (2002). Genetic resistance of the silkworm (B. mori L.) to viral disease. Curr. Sci., 83(4):439-446.

Table 1. Performance Of Multivoltine Silkworm Races For Different Economic Traits.

\begin{tabular}{|l|l|l|l|l|l|l|l|l|}
\hline Name of the race & $\begin{array}{l}\text { Larval } \\
\text { duration } \\
\text { (days) }\end{array}$ & $\begin{array}{l}\text { Wt. of } 10 \\
\text { mature } \\
\text { larvae }(\mathrm{g})\end{array}$ & $\begin{array}{l}\text { Dicease } \\
\text { incidence } \\
(\%)\end{array}$ & $\begin{array}{l}\text { Single } \\
\text { cocoon } \\
\text { weight }(\mathrm{g})\end{array}$ & $\begin{array}{l}\text { Shell ratio } \\
(\%)\end{array}$ & $\begin{array}{l}\text { Cocoon } \\
\text { yield } \\
(\mathrm{kg})\end{array}$ & $\begin{array}{l}\text { Deneir } \\
(\mathrm{No}) \\
\text { eggs }) \\
\text { of }\end{array}$ \\
\hline Pure Mysore & 29.53 & 15.45 & $1.50(0.85)$ & 0.646 & $14.41(8.28)$ & 6.467 & 1.94 & 508.61 \\
\hline Hosa Mysore & 23.27 & 21.02 & $7.85(4.50)$ & 0.935 & $16.10(9.26)$ & 9.350 & 2.00 & 456.66 \\
\hline Mysore Princess & 23.37 & 19.80 & $2.82(1.620$ & 0.792 & $14.67(8.43)$ & 7.927 & 1.84 & 458.32 \\
\hline Kolar Gold & 23.22 & 22.16 & $1.90(1.08)$ & 0.970 & $13.94(8.01)$ & 9.700 & 1.79 & 481.65 \\
\hline C. Nichi & 22.96 & 20.20 & $2.59(1.48)$ & 0.930 & $14.75(8.48)$ & 9.307 & 1.68 & 431.63 \\
\hline G Race & 23.66 & 20.42 & $2.91(1.66)$ & 0.770 & $15.02(8.63)$ & 7.700 & 1.72 & 434.31 \\
\hline$P_{2} D_{1}$ & 23.66 & 21.30 & $4.62(2.64)$ & 0.980 & $15.30(8.79)$ & 9.800 & 1.76 & 454.33 \\
\hline CB 5 & 23.26 & 20.61 & $2.48(1.42)$ & 0.872 & $14.77(8.49)$ & 8.720 & 1.91 & 462.96 \\
\hline Nistari & 24.21 & 18.93 & $5.40(3.09)$ & 0.905 & $14.53(8.35)$ & 9.067 & 1.87 & 436.86 \\
\hline S.E. \pm & 0.44 & 0.37 & 1.19 & 0.009 & 0.45 & 0.090 & 0.099 & 15.57 \\
\hline C.D. at $5 \%$ & 1.33 & 1.13 & 3.58 & 0.026 & 1.37 & 0.269 & 0.297 & 46.62 \\
\hline C.V. & 3.21 & 3.27 & 5.82 & 1.799 & 5.35 & 1.791 & 9.352 & 5.88 \\
\hline
\end{tabular}

* Figure in parenthesis indicate arcsine transformed values 